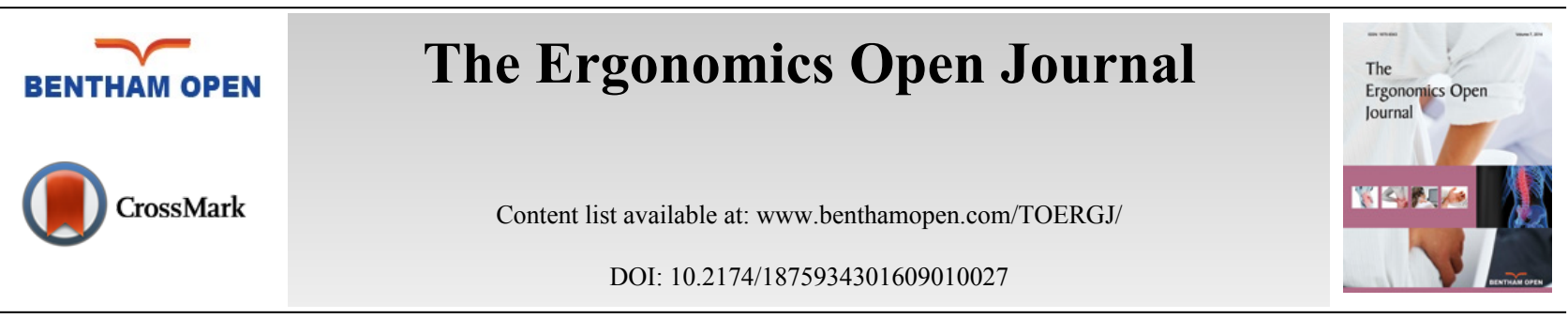

RESEARCH ARTICLE

\title{
The Importance of Safe Patient Handling to Create a Culture of Safety: An Evidential Review
}

\author{
Rob Humrickhouse, ${ }^{*}, 1$ and Hanneke J.J. Knibbe ${ }^{2}$ \\ ${ }^{1}$ Healthcare Consulting Services, 40 West Schiller St., Chicago, IL 60610, USA \\ ${ }^{2}$ LOCOmotion, Research in Healthcare, Brinkerpad 29, 6721WJ Bennekom, The Netherlands
}

Received: September 28, 2015

Revised: June 24, 2016

Accepted: August 15, 2016

\begin{abstract}
Manual patient handling has been linked to musculoskeletal disorders (MSDs) in healthcare workers. It can expose the musculoskeletal (MS) system of nurses and other healthcare workers to stress, and may put patients at risk for injury, pain and negative health outcomes. Creating a culture of safety around minimising manual patient handling is therefore thought to have a positive impact in diminishing the scope of this problem. Patient mobility is also an important clinical issue, and safe patient handling (SPH) and mobility technology can be used to promote mobilisation, to improve patient independence and quality of life.

There is evidence to suggest that multifactor interventions based on a risk assessment programme have the most likely chance of success in reducing risk factors associated with patient handling activities. The introduction of a structured SPH programme that pairs training with ergonomic intervention and mechanical aid use is now believed to be the most effective workplace intervention to prevent injuries relating to manual patient handling. The aim of this review is to investigate available evidence for the effectiveness of SPH programmes from the perspectives of healthcare worker safety, patient safety and cost. It is hoped that this will provide a broad view on the current state, significance and future potential of such programmes. Further, we consider what is missing from the available evidence, and how we can improve our understanding of SPH programme effectiveness in the healthcare setting.
\end{abstract}

Keywords: Back pain, Cultural change, Ergonomics, Musculoskeletal disorder, Occupational health, Safe patient handling, Safety, Training.

\section{INTRODUCTION}

Manual patient handling, although historically regarded as normal practice in healthcare facilities [1], is now generally regarded as unsafe for both caregivers and patients. It has also been linked to musculoskeletal disorders (MSDs) in healthcare workers [2 - 4]. The introduction of a structured safe patient handling (SPH) programme that pairs training with ergonomic intervention is now believed to be the most effective workplace intervention to prevent injuries relating to manual patient handling [5 - 9].

The safety climate of a healthcare organisation has been associated with both patient and nurse injuries and the two may be related, sharing common underlying causes [10]. Today's healthcare environment is challenging for its workers, and creating a culture of safety around minimising manual patient handling is thought to have a positive impact in diminishing the scope of this problem [1,11]. Manual handling can also be unsafe for patients, putting them at risk for injury, pain and negative health outcomes, partly due to the effects on caregivers-a caregiver under physical stress or with an injury is less likely to undertake high-risk manual patient handling tasks, and also could inadvertently cause patient injury or skin damage during a transfer $[1,12]$. There is evidence to suggest that training alone does not work, and increasing consensus that the use of ergonomic intervention and devices plays an important role in reducing MSD risk in nursing staff [13 - 18]. The US Centers for Disease Control and Prevention (CDC) state on their website that

\footnotetext{
* Address correspondence to this author at the Principal, Healthcare Consulting Services, 40 West Schiller St., Chicago, IL 60610, USA; Tel/Fax: 773-550-2499; E-mail: humrob@me.com
} 
SPH interventions guided by ergonomic principles (i.e. use of ergonomic devices and safety procedures in patient handling), have demonstrated efficacy in reducing overexertion injuries [19]. Further, available evidence suggests that multifactor interventions based on a risk assessment programme have the most likely chance of success in reducing risk factors associated with manual patient handling activities [8, 12, 20].

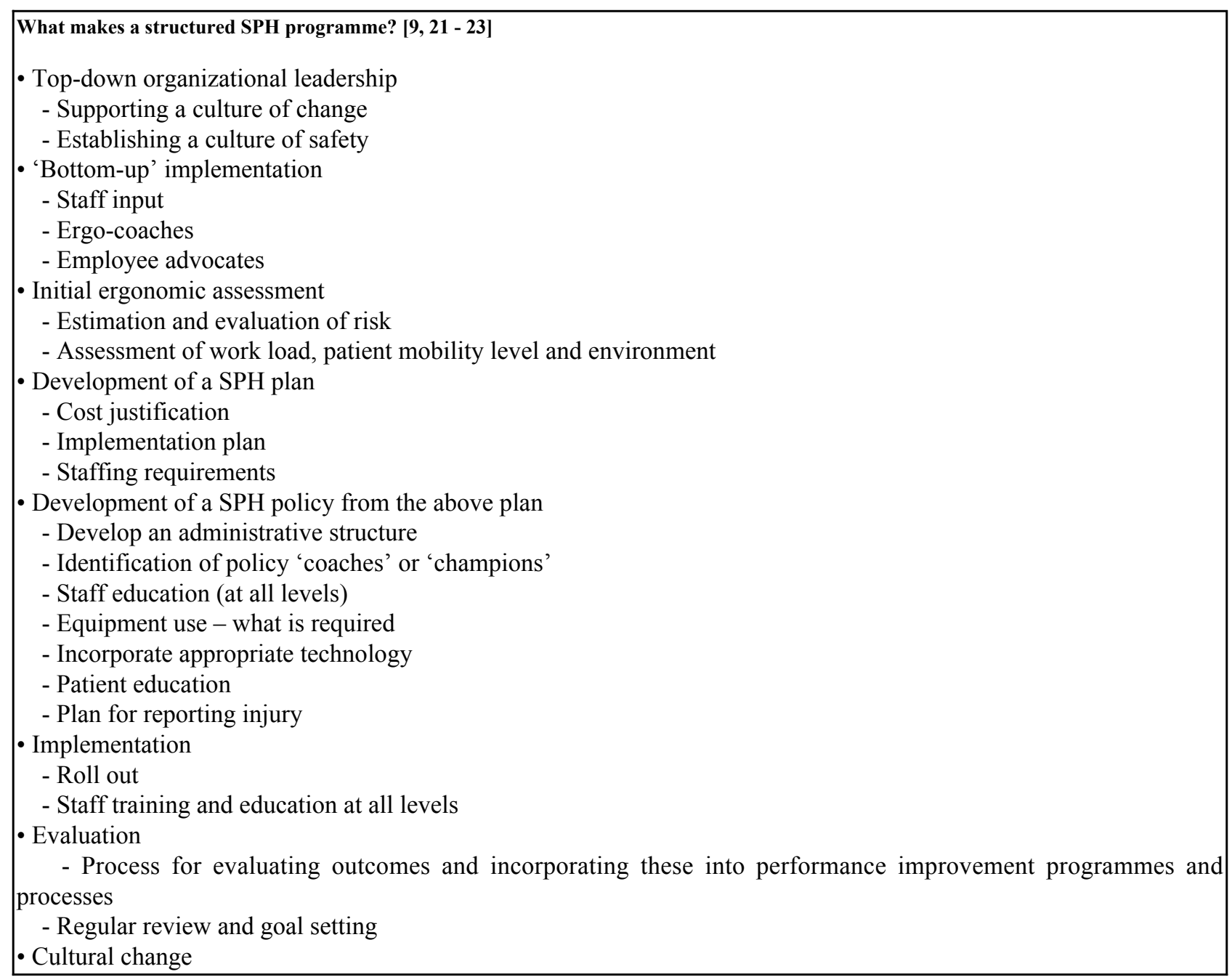

Manual patient handling can expose the musculoskeletal (MS) system of nurses and other healthcare workers to stress, leading to MSDs. Repeatedly and continuously performing manual patient handling tasks, such as lifting, transferring and repositioning throughout working life increases the risk of MSDs; this risk runs across all areas of nursing $[4,24]$ (see Table 1). MSDs are a major source of injury to healthcare workers, and are especially prevalent in physical therapists $[25,26]$. The consequences of these injuries include pain, functional disability and time away from work in healthcare workers, as well as costs to employers (i.e. medical expenses, disability compensation and litigation) [23] (see Table 3). This has an important causal effect on healthcare systems, as anything that takes staff away from patient care (be it injury, work limitations, or other factors) creates cost issues in a system (national or private healthcare), and has the potential for reducing the overall safety of the unit, including that of the patient. Manual patient handling is considered by many to be the single greatest risk factor for overexertion injuries in healthcare workers, while growing obesity rates and the increasing age of the nursing workforce are also contributory factors [1, 4, 11].

Manual patient handling may also restrict a patient's opportunities for mobility-impacting on recuperation, rehabilitation and general health (see Table 2). This, importantly, can affect patient and caregiver quality of life [1], and patient dignity [27]. Limited mobility is also a risk factor for pressure ulcer development [28], and guidelines emphasise the regular turning and repositioning of patients as a strategy to prevent pressure ulcers [29, 30]. The American Nurses Association (ANA) made the decision to add the term 'mobility' when discussing SPH, to recognise that both healthcare worker and recipient should have an active involvement in progressing the activity and mobility level of the healthcare recipient. SPH and mobility technology should be used to promote patient mobilisation with the goal of 
rehabilitation and restoring independence. Quality of care should be increased, while decreasing the injury risk to both healthcare recipient and worker [31,32].

The purpose of this review was to provide an historical overview of the effectiveness of SPH programme implementation, from the perspectives of healthcare worker safety, patient safety and cost, based on available evidence (see Table 4). Existing systematic reviews point to a multifactorial origin for occupational back pain in nursing, and indicate that effective interventions tend to be complex and multidimensional in nature. Further, most research only describes the content of the actual intervention in a limited way, making its exact nature unclear. Based on this information, we decided to study the literature for further indications of the effect of interventions, their exact content and procedure, and evidence for the principles that appear to make them either effective or ineffective. These indications can be evidence-based, but equally may be only descriptive. We have therefore also included studies in our search with a less strict design and a more-thorough description of the intervention.

PubMed searches were performed on relevant keywords (i.e. patient handling, patient transfer AND intervention, prevent*, ergo*, physical load, physical exposure, mechanical exposure, musculoskeletal disorder, musculoskeletal injury). The results from these searches were used as the basis for an overview of the evidence, as detailed above. Although a wide variety of sources were used in the introduction and discussion sections, the review section itself includes primarily papers from peer-reviewed journals. As the aim of this review was to provide a broad, evidential view on the current state, significance and future potential of SPH programmes, the process used to identify suitable publications for inclusion was based on their contribution to the evidence base for what works in SPH, rather than a systematic approach. We acknowledge the fact that systematic reviews will be needed to supplement knowledge of this field by building and expanding on our evidential review. It is hoped that this review will provide a broad view on the current state, significance and future potential of such programmes. Further, we consider what is missing from the available evidence, and what additional studies may need to take place to improve our understanding of SPH programme effectiveness in the healthcare setting.

\section{SAFE PATIENT HANDLING IN PRACTICE AND LEGISLATION}

\section{In the US}

The United States OSHA recognises SPH as an important necessity to minimise the risk of MSDs in healthcare workers, and states that the use of ergonomic devices is beneficial to patients as well as healthcare workers. Legislation varies in the US, but California, Illinois, Hawaii, Maryland, Minnesota, New Jersey, New York, Ohio, Rhode Island, Texas and Washington have all implemented state legislation relating to SPH. There is no SPH law at the federal level as of November 2015; the most recently introduced relevant federal legislation is the Nurse and Health Care Worker Protection Act of 2013 [33]. This directs the Secretary of Labor to issue an occupational safety and health standard to establish a standard for SPH, mobility and injury prevention to reduce injury to patients, nurses and other healthcare workers [19, 23, 33]. The National Institute for Occupational Safety and Health (NIOSH) is also concerned with occupational injuries, and has a focused programme designed to minimise these injuries in the Healthcare and Social Assistance (HCSA) through a research and prevention programme [19]. The OSHA and the Association of Occupational Health Professionals (AOHP) have also collaborated to develop a guide on implementing a SPH programme in the acute care setting, which was revised in 2011 and is now in its second edition [21].

In 2003, the ANA began a 'Handle with Care' Campaign to address work-related MSDs [34]. This prompted the eleven US states listed above to enact SPH laws or regulations, with Hawaii passing a resolution. Ten of these eleven require a comprehensive programme in healthcare facilities - with established policy, guidelines for equipment and training, data collection and evaluation [35]. In June 2013 the ANA published eight Interprofessional National Standards of SPH and Mobility which are intended for use by nurses and other healthcare workers. These outline the role of both the employer and their healthcare professionals across a range of healthcare settings [22], and are accompanied by a step-by-step guidance document on implementing these Standards. Further, the ANA strongly supports actions and policies to encourage SPH in healthcare institutions, and in January 2014 published a briefing paper highlighting the potential cost-effectiveness of SPH and mobility programmes [36, 37].

The OSHA's Guidelines for Nursing Homes: Ergonomics for the Prevention of Musculoskeletal Disorders recommend that manual patient handling should be minimised in all cases, and where possible, eliminated. OSHA recommends that these guidelines are adopted in acute care facilities. They are not formal standards for SPH, but OSHA recommends that ergonomic considerations are implemented through the general duty clause which requires that every 
employer should provide a safe and hazard-free work environment. There is a considerable amount of variation in the level to which SPH laws or regulations are enforced. Some states have not published rules for implementation, even though they have passed legislation, so the laws are not always implemented in healthcare institutions, or applied during inspections. The American Physical Therapy Association (APTA), the Association of Rehabilitation Nurses (ARN), and the Veterans Administration have also formed a collaboration to implement SPH and the use of equipment [21].

\section{In Europe}

The European Union (EU) has a directive on manual handling in the health and social care industries [38], which was introduced in 1990. In 1992, the UK implemented the Manual Handling Operations Regulations (these were amended in 2002), which states that employers must "avoid the need for hazardous manual handling, so far as is reasonably practicable" [39]. Manual handling legislation is also in place in the Netherlands, Switzerland, Australia, Finland, Ireland, and Canada [21]. In June 2012, the International Organisation for Standardisation (ISO), a global federation of national standards bodies, published a Technical Report (TR) on Ergonomics: Manual Handling of People in the Healthcare Sector. This was developed by an international standards Technical Committee (ISO/TC 159, Ergonomics, Subcommittee SC 3, Anthropometry and Biomechanics), which represented 23 participating and 12 observing countries, with expert support from the European Panel on Patient Handling Ergonomics (EPPHE) - now known as the International Panel on Patient Handling Ergonomics (IPPHE). The stated aim of the TR was to provide guidance in assessing problems and risks associated with manual patient handling; identifying and applying ergonomic strategies and solutions. It provides an overview of evidence-based methods to identify hazards and evaluate the risks associated with manual patient handling, while advising on the application of strategies and solutions to reduce risks associated with this $[9,40]$.

\section{THE IMPORTANCE OF SAFE PATIENT HANDLING - SUPPORTING EVIDENCE}

\section{In Relation to Healthcare Workers: Ergonomic Devices and/or SPH Programmes}

A number of studies have reviewed the impact of ergonomic device and/or SPH programme use on healthcare worker injury and practice. Overall, most found a decreased injury rate and risk with ergonomic device introductionparticularly in reducing MSDs [41 - 43]; staff perception of injury risk was also reduced with ceiling lifts [44]. The number of lost workdays due to injury was also generally reduced with introduction of ergonomic devices [7, 43, 45], as were costs associated with patient handling-related injury [45]. Use of ergonomic devices was also associated with reduced awkward back posture incidence and duration [46], safer patient transfers [47], and reduced risk of infrequent lower back pain [48]. Burdorf et al. reported, however, that even the best scenario only showed a maximal reduction of $14 \%$ in lower back pain prevalence, while the projection from this analysis was that complete elimination of manual patient lifting would reduce lower back pain by $10.5 \%$ [43].

Implementation of an ergonomic intervention programme was found by most studies to reduce back MSDs in healthcare staff [12 - 18], with several further concluding that training can increase knowledge of risk and improve behaviour with regard to reducing manual patient handling and associated risks [5, 14, 49]. One study found that the ergonomic programme was no more effective than basic education in reducing or preventing lower back pain [50]. In general, however, a reduction in lost workdays due to injury was also found with ergonomic programme implementation $[15,16,18,51]$, as were reductions in injury-related costs $[16,51]$. The quality of the study evidence overall is not high; some are small [13, 14, 41], not randomised [4, 16, 42, 46, 49, 52], or lacking appropriate controls $[4,12,16,17,45,49,50]$, or include other factors which may have an influence on the study result $[44,48,51]$.

Table 1. Evidence summary - healthcare workers and SPH.

\begin{tabular}{|l|l|l|}
\hline $\begin{array}{c}\text { First author } \\
\text { and year }\end{array}$ & Summary of study & Evidence \\
\hline \multicolumn{2}{|c|}{ Intervention involving just device use } \\
\hline $\begin{array}{l}\text { Trinkoff } \text { et al. } \\
2003[42]\end{array}$ & $\begin{array}{l}\text { Randomly selected working nurses surveyed }(\mathrm{N}=1163) \\
\text { via an anonymous mailed survey in the US. }\end{array}$ & $\begin{array}{l}\text { Mechanical lifting device availability was associated with a significantly } \\
\text { reduced likelihood of neck and back MSDs; back injury was less likely } \\
\text { when lifting teams were available. It could be argued that data collection } \\
\text { by anonymous mailed survey may bias the study population towards } \\
\text { nurses with injury or concerns relating to SPH. }\end{array}$ \\
\hline
\end{tabular}




\begin{tabular}{|c|c|c|}
\hline $\begin{array}{l}\text { First author } \\
\text { and year }\end{array}$ & Summary of study & Evidence \\
\hline $\begin{array}{l}\text { Evanoff et al. } \\
2003 \text { [7] }\end{array}$ & $\begin{array}{l}\text { Review of injury rates and lost workdays both before and } \\
\text { after mechanical lift in } 4 \text { acute care hospitals and } 5 \text { long- } \\
\text { term care facilities ( } 36 \text { intervention units) in the US. The } \\
\text { study population was followed for } 5 \text { years (including 2-3 } \\
\text { years post-intervention). }\end{array}$ & $\begin{array}{l}\text { MSD rates, lost workday injuries, and days lost due to injury were } \\
\text { reduced post-intervention. Higher self-reported lift use frequency in the } \\
\text { long-term care facilities (also greater MSD rate reductions, compared } \\
\text { with hospitals). Correlation seen between higher self-reported lift use } \\
\text { and reductions in injury and lost day injury rates. }\end{array}$ \\
\hline $\begin{array}{l}\text { Li et al. } 2004 \\
{[41]}\end{array}$ & $\begin{array}{l}\text { Effectiveness of mechanical patient lifts studied pre- and } \\
\text { post-intervention in workers at a US community hospital } \\
(\mathrm{N}=36) .\end{array}$ & $\begin{array}{l}\text { Reduced injury rate and symptoms relating to MSDs reported post- } \\
\text { intervention; statistically significant improvement in MS comfort } \\
(\mathrm{p}<0.05) \text { reported for all } 9 \text { body parts surveyed - this included shoulders, } \\
\text { lower back and knees. The study limitations include the pre-post study } \\
\text { design, and a small sample size. }\end{array}$ \\
\hline $\begin{array}{l}\text { Chhokar et al. } \\
2005[45]\end{array}$ & $\begin{array}{l}\text { Assessment of overhead lifts in an extended care facility } \\
\text { in Canada, with analysis of injury trends over } 3 \text { years pre- } \\
\text { intervention, and } 3 \text { years post-intervention. }\end{array}$ & $\begin{array}{l}\text { Significant and sustained decrease found post-intervention in patient } \\
\text { handling injury-related direct costs }(\mathrm{p}=0.034) \text { and number of days lost } \\
(\mathrm{p}=0.024) \text {. The number of patient-handling claims decreased from } 65 \\
\text { pre-intervention to } 47 \text { post-intervention, and the number of all MS injury } \\
\text { claims decreased significantly }(\mathrm{p}=0.006) \text {. Difficult to differentiate } \\
\text { between the effects of device implementation, and of an injury reduction } \\
\text { and training programme overall. No formal, randomised control group } \\
\text { included. }\end{array}$ \\
\hline $\begin{array}{l}\text { Miller et al. } \\
2006[44]\end{array}$ & $\begin{array}{l}\text { Assessment of ceiling lift introduction. Matched pre- and } \\
\text { post-intervention questionnaires comparing patient } \\
\text { handling injuries were completed by front-line care staff } \\
\text { from intervention }(\mathrm{n}=17) \text { and control }(\mathrm{n}=15) \text { facilities in } \\
\text { Vancouver, Canada. }\end{array}$ & $\begin{array}{l}\text { Staff perception of injury risk was significantly lower }(\mathrm{p}<0.05) \text { when } \\
\text { ceiling lifts were used compared with manual transfer methods; } 82 \% \text { of } \\
\text { staff believed that lifting patients was easier to perform using ceiling lifts } \\
\text { compared with other methods such as floor lifts. }\end{array}$ \\
\hline $\begin{array}{l}\text { Koppelaar et } \\
\text { al. } 2012[46]\end{array}$ & $\begin{array}{l}\text { Ergonomic device use assessed by } 186 \text { nurses on } 735 \\
\text { patient handling activities in } 17 \text { nursing homes in the } \\
\text { Netherlands, in real time, using a structured patient } \\
\text { handling programme centred on the presence of a ward } \\
\text { Ergo or Transfer Mobility coach (a specialist trained in } \\
\text { ergonomic principles who is responsible for supporting } \\
\text { this process). }\end{array}$ & $\begin{array}{l}\text { Reported ergonomic device use of } 69 \% \text {; use of anti-embolism stocking } \\
\text { slide and lifting devices associated with lower frequency of exerted } \\
\text { forces, and adjustable bed and shower chairs with shorter awkward back } \\
\text { posture duration. Device use also associated with less forceful } \\
\text { movements and fewer awkward back postures; using lifting devices } \\
\text { during patient transfers reduced exerted forces by two-thirds. The } \\
\text { nursing homes included were not selected at random, and targeted for } \\
\text { coach employment. }\end{array}$ \\
\hline $\begin{array}{l}\text { Knibbe et al. } \\
2012[47]\end{array}$ & $\begin{array}{l}\text { Analysis of } 213 \text { horizontal patient transfers }(87 \% \\
\text { heavy/very heavy) in the Netherlands. }\end{array}$ & $\begin{array}{l}\text { Introduction of stretcher slings increased the number of safe transfers } \\
\text { performed from } 29.5 \% \text { to } 83.6 \% \text {, reducing the number of nurses } \\
\text { required. }\end{array}$ \\
\hline $\begin{array}{l}\text { Burdorf et al. } \\
2012[43]\end{array}$ & $\begin{array}{l}\text { A literature analysis of patient lifting device use in } \\
\text { healthcare settings. A Markov decision analysis model } \\
\text { was used to assess studies on the effect of manually } \\
\text { lifting patients, and on introducing lifting devices on } \\
\text { lower back pain and related injury claims. }\end{array}$ & $\begin{array}{l}\text { Implementation of lifting devices was found to reduce lower back pain } \\
\text { and related claims, but the best scenario only showed a maximal } \\
\text { reduction of } 14 \% \text { in lower back pain prevalence, and of MSD injury } \\
\text { claims from } 5.8 \text { to } 5.6 \text { per } 100 \text { work years. The projection from this } \\
\text { analysis was that complete elimination of manual patient lifting would } \\
\text { reduce lower back pain by } 10.5 \% \text {, and MSD injury claims to } 4.3 \text { per } 100 \\
\text { work years. }\end{array}$ \\
\hline $\begin{array}{l}\text { Holtermann } \\
\text { et al. } 2015 \text { [48] }\end{array}$ & $\begin{array}{l}\text { A prospective cohort study of female healthcare workers } \\
\text { (elder care services; } N=1,478 \text { ), with no reported lower } \\
\text { back pain at baseline. Questionnaires on assistive device } \\
\text { use were sent to participants; screening was post- } \\
\text { response. }\end{array}$ & $\begin{array}{l}\text { In those workers occasionally using assistive devices, the multi-adjusted } \\
\text { OR for developing infrequent lower back pain was } 1.21 \text { (95\% CI } \\
0.90-1.62) \text {, compared with an OR of } 1.78 \text { ( } 95 \% \text { CI } 1.19-2.66) \text { for those } \\
\text { rarely using assistive devices. A significant trend was found between } \\
\text { frequency of assistive device during patient handling and the risk for } \\
\text { infrequent lower back pain }(p<0.01) \text {, with rare use associated with an } \\
\text { increased infrequent lower back pain risk; no increased risk for frequent } \\
\text { lower back pain was found. }\end{array}$ \\
\hline \multicolumn{3}{|c|}{ Intervention involving device use and/or ergonomic strategy } \\
\hline $\begin{array}{l}\text { Garg et al. } \\
1992[13]\end{array}$ & $\begin{array}{l}\text { Prospective, epidemiologic study reviewing an ergonomic } \\
\text { intervention strategy to reduce back stress in healthcare } \\
\text { providers. Conducted in two units of a US nursing home } \\
\text { (140 beds; } 57 \text { nursing assistants). }\end{array}$ & $\begin{array}{l}\text { Decrease in incidence rate for back MSDs from } 83 \text { per } 200,000 \text { work- } \\
\text { hours pre-intervention, to } 47 \text { per } 200,000 \text { work-hours post- intervention. }\end{array}$ \\
\hline $\begin{array}{l}\text { Lynch and } \\
\text { Freund } 2000 \\
{[14]}\end{array}$ & $\begin{array}{l}\text { Analysis of a one-year Back Injury Prevention } \\
\text { Programme at an acute care hospital in the US, with } \\
\text { ergonomic evaluation of patient handling, pilot testing } \\
\text { and purchase of new equipment, a train-the-trainer } \\
\text { programme, and training of approximately } 50 \% \text { of } \\
\text { nursing staff ( } 374 \text { nurses, and other patient handling } \\
\text { staff). Efficacy was evaluated using self-reported } \\
\text { knowledge, work practices and back pain in a subset of } \\
\text { trainees and controls. }\end{array}$ & $\begin{array}{l}\text { Risk factor knowledge was increased post-implementation; a marginal } \\
\text { increase was seen in mechanical device use for patient transfer, while } \\
\text { repositioning of patients in bed was significantly decreased ( } \mathrm{p}=0.017) \text {. } \\
\text { Back MSDs were reduced by } 30 \% \text { from the average of the previous } 3 \\
\text { years, with the number of reported injuries reduced in the quarter } \\
\text { immediately following the training programme. }\end{array}$ \\
\hline
\end{tabular}




\begin{tabular}{|c|c|c|}
\hline $\begin{array}{c}\text { First author } \\
\text { and year }\end{array}$ & Summary of study & Evidence \\
\hline $\begin{array}{l}\text { Brophy et al. } \\
2001 \text { [15] }\end{array}$ & $\begin{array}{l}\text { Study reporting on implementation of a 5-step } \\
\text { ergonomics programme in a US nursing home over a 7- } \\
\text { year period, with the aim of changing behaviour across all } \\
\text { levels. Health and financial outcomes were compared pre- } \\
\text { and post-intervention. }\end{array}$ & $\begin{array}{l}\text { Mean number of MSDs was significantly reduced - from } 15.7 \text { per } 100 \\
\text { pre-intervention, to } 11.0 \text { per } 100 \text { post-intervention }(\mathrm{p}=0.05) \text {. Number of } \\
\text { lost workdays was also significantly reduced, from } 1476 / \text { year pre- } \\
\text { intervention to } 625 / \text { year post-intervention }(\mathrm{p}=0.05) \text {. }\end{array}$ \\
\hline $\begin{array}{l}\text { Yassi et al. } \\
2001 \text { [5] }\end{array}$ & $\begin{array}{l}\text { Three-armed RCT (control, safe lifting and no strenuous } \\
\text { lifting) on the effectiveness of training and equipment in } \\
\text { reducing MSD injury in staff undertaking patient } \\
\text { handling (N=346 [nurses and unit assistants]) in a } \\
\text { Canadian acute care hospital. Training in handling } \\
\text { techniques, patient assessment and back care received by } \\
\text { both intervention arms; the 'no strenuous lifting' arm also } \\
\text { aimed to eliminate manual patient handling by using } \\
\text { mechanical and other assistive equipment. }\end{array}$ & $\begin{array}{l}\text { The frequency of manual handling tasks was significantly decreased in } \\
\text { the 'no strenuous lifting' arm ( }<0.001) \text {; self-perceived work fatigue, } \\
\text { back and shoulder pain, safety, and frequency and intensity of physical } \\
\text { discomfort associated with patient handling tasks improved in both } \\
\text { intervention arms - with greater improvement in the 'no strenuous } \\
\text { lifting' arm. }\end{array}$ \\
\hline $\begin{array}{l}\text { Johnsson et al. } \\
2002 \text { [49] }\end{array}$ & $\begin{array}{l}\text { A training programme in patient handling and moving } \\
\text { skills was evaluated ( } \mathrm{N}=51 \text { healthcare providers in } \\
\text { Sweden), based on video-recordings before and after } \\
\text { training, plus questionnaire both before and } 6 \text { months } \\
\text { post-training (physical exertion, job strain, and MSD } \\
\text { problems). }\end{array}$ & $\begin{array}{l}\text { No significant decrease in MSDs was found post-training, but physical } \\
\text { exertion following bed-to-chair transfer was reduced after training } \\
\text { programme completion, and } 98 \% \text { of participants positively reported on } \\
\text { their participation in training, which also led to improved work } \\
\text { technique. }\end{array}$ \\
\hline $\begin{array}{l}\text { Owen } \text { et al. } \\
2002 \text { [6] }\end{array}$ & \begin{tabular}{|l|} 
An intervention study and follow up in two US hospitals \\
(ergonomic programme with assistive patient handling \\
devices [ $\mathrm{n}=37]$ and control $[\mathrm{n}=20]$ ) on perceived exertion \\
felt by nursing staff undertaking patient handling tasks. \\
Data collection forms were used to assess injury data and \\
lost and restricted workdays following programme \\
implementation.
\end{tabular} & $\begin{array}{l}\text { Mean differences in perceived exertion to shoulder and to lower back } \\
\text { were statistically significant between the control and experimental } \\
\text { hospitals ( } \mathrm{p}<0.001 \text { ), with a concomitant decrease in the number of back } \\
\text { MSDs (from } 20 \text { pre-intervention, to } 12 \text { post-intervention) and of } \\
\text { lost/restricted work days (from } 64 \text { pre-intervention, to } 3 \text { post- } \\
\text { intervention). }\end{array}$ \\
\hline $\begin{array}{l}\text { Collins et al. } \\
2004 \text { [16] }\end{array}$ & $\begin{array}{l}\text { Six-year intervention trial of a back injury prevention } \\
\text { programme in } 1728 \text { nursing personnel, in six US nursing } \\
\text { homes. }\end{array}$ & $\begin{array}{l}\text { Significant reduction in incidence of patient handling-related injury } \\
(\text { p }<0.05) \text {, with a reduction also in lost work day injuries (from } 5.8 \text { to } 2.0 \\
\text { per } 100 \text { personnel) following programme implementation. }\end{array}$ \\
\hline \begin{tabular}{|l|} 
Hartvigsen \\
et al. 2005 [50]
\end{tabular} & $\begin{array}{l}\text { Evaluation of an education and low-tech ergonomic } \\
\text { intervention programme in } 345 \text { Danish nurse's aides and } \\
\text { home care nurses. }\end{array}$ & $\begin{array}{l}\text { The ergonomic programme was no more effective than basic education } \\
\text { in reducing or preventing lower back pain, but any education in training } \\
\text { transfer techniques was associated with an improvement in back pain, } \\
\text { and was considered by participants as helpful. }\end{array}$ \\
\hline $\begin{array}{l}\text { Fujishiro et al. } \\
2005 \text { [17] }\end{array}$ & $\begin{array}{l}\text { Evaluation of MSD rate changes between baseline (1 year } \\
\text { pre-intervention) and post-intervention (up to } 2 \text { years) in } \\
100 \text { work units in } 86 \text { healthcare facilities in the US ( } 73 \\
\text { nursing homes, } 10 \text { MR/DD facilities and } 3 \text { hospitals) in a } \\
\text { programme for ergonomic consultation and financial } \\
\text { support for ergonomic device purchase, with a 2-year data } \\
\text { collection follow-up period. Comparison with BLS data } \\
\text { used instead of controls. }\end{array}$ & $\begin{array}{l}\text { Median MSD rate decreased post-intervention to } 6.64 \text { per } 200,000 \\
\text { employee-hours, from } 12.32 \text { per } 200,000 \text {. Each intervention type } \\
\text { (reduction of bending, elimination of lifting, reduction of lifting, and a } \\
\text { combination of the three) was associated with reduced MSD rates, and } \\
\text { post-intervention MSD rates were considerably lower than comparable } \\
\text { BLS-reported national rates. }\end{array}$ \\
\hline $\begin{array}{l}\text { Nelson et al. } \\
2006 \text { [12] }\end{array}$ & \begin{tabular}{|l} 
Implementation of an ergonomics programme \\
incorporating evidence-based practice, technology and \\
safety improvement, evaluated prospectively in 23 high- \\
risk units (19 nursing home care units and 4 spinal cord \\
injury units) in 7 facilities in the US. Injury rates, lost \\
work days, modified work days, job satisfaction, staff and \\
patient acceptance, programme effectiveness, and \\
programme costs/savings were compared over a nine- \\
month pre-intervention period, and a nine-month post- \\
intervention period, in 875 nursing staff.
\end{tabular} & $\begin{array}{l}\text { MSDs and the number of modified duty days taken per injury decreased } \\
\text { significantly ( } \mathrm{p}=0.036 \text { and } \mathrm{p}=0.02 \text {, respectively), with post-intervention } \\
\text { injury rate reduced in } 15 \text { of the } 23 \text { units. An } 18 \% \text { decrease was seen in } \\
\text { the total number of lost work days. The number of 'unsafe' patient } \\
\text { handling practices performed daily was self-reportedly decreased } \\
\text { significantly ( } \mathrm{p}=0.027) \text {, with equipment being rated by nurses as the } \\
\text { most effective programme element, followed by a No Lift Policy. }\end{array}$ \\
\hline $\begin{array}{l}\text { Charney et al. } \\
2006 \text { [51] }\end{array}$ & \begin{tabular}{|l|} 
Data on patient handling injuries was compared before \\
and after implementation of a 'zero-lift' programme in 31 \\
US hospitals (replacement of manual patient lifting, \\
transferring and repositioning with mechanical \\
lifting/other devices).
\end{tabular} & $\begin{array}{l}\text { Patient handling injury claims were decreased by } 43 \% \text { (from } 3.88 \text { per } \\
100 \text { full time equivalents [FTEs] pre-intervention, to } 2.23 \text { per } 100 \text { FTEs } \\
\text { post-intervention). Lost time frequency decreased from } 1.91 \text { FTEs pre- } \\
\text { intervention, to } 1.03 \text { per } 100 \text { FTEs post-intervention. }\end{array}$ \\
\hline $\begin{array}{l}\text { Muto et al. } \\
2008 \text { [52] }\end{array}$ & $\begin{array}{l}\text { A non-randomized intervention study in care staff in two } \\
\text { schools for children with disabilities. Intervention } \\
\text { included use of nursing assistance tools }(\mathrm{n}=21) v s \text {. control } \\
(\mathrm{n}=20) \text { groups. }\end{array}$ & $\begin{array}{l}\text { No significant difference in lower back pain prevalence was seen in } \\
\text { either group. Upper arm pain decreased in the intervention group from } \\
47.6 \% \text { at baseline to } 23.8 \% \text { at end point }(\mathrm{p}=0.063) \text {; high lower back } \\
\text { burden decreased in the intervention group from } 57.1 \% \text { at baseline to } \\
33.3 \% \text { at end point }(\mathrm{p}=0.063) \text {. No significant impact was seen on low } \\
\text { back pain, and depression. }\end{array}$ \\
\hline
\end{tabular}




\begin{tabular}{|c|c|c|}
\hline $\begin{array}{l}\text { First author } \\
\text { and year }\end{array}$ & Summary of study & Evidence \\
\hline $\begin{array}{l}\text { Garg \& } \\
\text { Kapellusch } \\
2012[18]\end{array}$ & $\begin{array}{l}\text { Long-term effects of ergonomic programme } \\
\text { implementation with patient handling device installation } \\
\text { in six long-term care facilities and one chronic care } \\
\text { hospital in the US, plus a control group. Injury data was } \\
\text { collected for an average of } 38.9 \text { months pre-intervention } \\
\text { and } 51.2 \text { months post-intervention. }\end{array}$ & $\begin{array}{l}\text { Patient handling injuries decreased by } 59.8 \% \text { post-intervention }(p<0 \\
.001) \text {, and lost workdays by } 86.7 \%(p<0.001) \text {. All devices were rated as } \\
\text { less stressful on the low back }(p<0.001) \text {, shoulders }(p \leq 0.008) \text {, and wrists } \\
(p \leq 0.005) \text {. Post intervention, no problems in performing their tasks } \\
\text { (including patient lifting) were experienced by pregnant or older } \\
\text { participants, or those with back problems, and the lifts were rated as } \\
\text { more comfortable and safe by the majority of patients. }\end{array}$ \\
\hline $\begin{array}{l}\text { Kuijer et al. } \\
2014 \text { [53] }\end{array}$ & $\begin{array}{l}\text { Evidence-based practice guideline developed by a team of } \\
\text { occupational health and safety professionals, based on a } \\
\text { systematic literature review. }\end{array}$ & $\begin{array}{l}\text { - Training and advice may theoretically reduce low back load, but this } \\
\text { is unlikely to be achieved and upheld in practice } \\
\text { - Patient lifting devices can remove the need for manual lifting, but } \\
\text { low back loading can still occur } \\
\text { - Lifting belts can help to reduce low back loading } \\
\text { - Lifting teams can reduce the number of patient lifts performed } \\
\text { - Team lifting does not increase the risk for lower back pain }\end{array}$ \\
\hline
\end{tabular}

\section{In Relation to Patients and Outcomes}

Fewer investigations of SPH programmes were found that focus specifically on patient wellbeing. Arnold et al. found that discharge mobility functional independence (FIM) ratings were higher in patients managed with a SPH approach [54]. As this study was observational and nonexperimental, the authors caution that these results cannot provide direct evidence of causality and should be interpreted cautiously [54]. SPH programmes can substantially impact rehabilitation services, combining functional mobility support and training, with use of ergonomic equipment to support/guide the patient. Advantages in using this equipment in rehabilitation therapy were described by Campo et al., who reported that use of an SPH programme resulted in similar or slightly better mobility outcomes for the majority of the patients-mitigating concerns raised in the industry that such programmes may inhibit functional mobility. This was not a direct comparison, however, as the patients in the control group were treated at a different time, also patients in the SPH group had diagnoses of more medical complexity [55].

SPH programmes including ergonomic devices can improve patient quality of life, and concomitantly, psychological status. Nelson and colleagues found an improvement in physical functioning and levels of depression in patients after implementation of an ergonomics programme; urinary continence was also improved. No significant improvement was shown in mood or behaviour indicators, however, or cognition. This study relied on secondary data, had no control group, and was also a retrospective analysis [4], so it would be interesting to see what outcomes were achieved from a better-powered study. Owen et al. described a self-reported improvement in patient comfort and feeling secure when an ergonomic device was used [6], while Garg \& Kapellusch assessed patient ratings of lifting devices, reporting that the majority of patients found the devices to be comfortable and safe [18]. Although Gucer et al. found a higher fall risk with powered mechanical lift use, other benefits in resident outcomes were seen (a reduction in pressure ulcers, and fewer were bedfast) [56].

Table 2. Evidence summary - patients and SPH.

\begin{tabular}{|l|l|l|}
\hline $\begin{array}{c}\text { First author } \\
\text { and year }\end{array}$ & \multicolumn{1}{|c|}{ Summary of study } & \multicolumn{1}{|c|}{ Evidence } \\
\hline $\begin{array}{l}\text { Owen } \text { et al. } \\
2002[6]\end{array}$ & $\begin{array}{l}\text { An intervention study comparing assistive patient handling } \\
\text { devices with standard methods of patient handling (control) in } \\
\text { a US hospital. Injury data and lost and restricted workdays } \\
\text { following programme implementation were reviewed via use } \\
\text { of data collection forms. }\end{array}$ & $\begin{array}{l}\text { On a scale of 0-7 (extremely secure to extremely insecure), patients } \\
\text { reported feeling more comfortable and secure when an assistive } \\
\text { device was used - with a mean score for the experimental site of } \\
0.1-1.1 \text { and for the control site of } 2.7-4.3 ; \text { mean difference for all } \\
\text { patient handling tasks was significant }(p<0.001) .\end{array}$ \\
\hline $\begin{array}{l}\text { Nelson } \text { et al. } \\
2008[4]\end{array}$ & $\begin{array}{l}\text { Pre- and post-implementation assessment of patient care } \\
\text { quality in an ergonomics programme over 24 units of six US } \\
\text { Veterans Administration nursing homes }(\mathrm{N}=111 \text { residents). }\end{array}$ & $\begin{array}{l}\text { No significant change was seen in most health outcome variables. } \\
\text { Post-implementation improvement in patient physical functioning } \\
\text { was seen, with improved urinary continence, lower fall risk, and } \\
\text { improved daytime alertness and engagement in activities. Levels of } \\
\text { depression were also lower post-implementation. Pressure ulcer } \\
\text { incidence showed variable results, and differences were not } \\
\text { statistically significant. No significant improvement was shown in } \\
\text { mood or behaviour indicators, or cognition. }\end{array}$ \\
\hline
\end{tabular}




\begin{tabular}{|c|c|c|}
\hline $\begin{array}{c}\text { First author } \\
\text { and year }\end{array}$ & Summary of study & Evidence \\
\hline $\begin{array}{l}\text { Arnold et al. } \\
2012 \text { [54] }\end{array}$ & $\begin{array}{l}\text { A retrospective cohort study evaluating differences in } \\
\text { functional outcomes in patients with stroke treated with SPH } \\
\text { equipment and programme (Group 2), and without SPH } \\
\text { equipment (Group 1) }(\mathrm{N}=94 \text { ), in a US inpatient rehabilitation } \\
\text { centre. The mobility elements of the Functional Independence } \\
\text { Measure (FIM) assessment tool were used to perform a } \\
\text { retrospective analysis of patient ratings. }\end{array}$ & $\begin{array}{l}\text { Higher discharge mobility FIM ratings were seen in Group } 2 \text { patients } \\
\text { compared with Group 1; both groups demonstrated significant } \\
\text { improvements in FIM mobility ratings at discharge. The Group } 2 \\
\text { patients improved more than the Group } 1 \text { patients in } 4 / 5 \text { FIM } \\
\text { mobility categories. No significant effect was seen on length of stay. }\end{array}$ \\
\hline $\begin{array}{l}\text { Garg \& } \\
\text { Kapellusch } \\
2012[18]\end{array}$ & $\begin{array}{l}\text { Long-term effects of ergonomic programme implementation } \\
\text { with patient handling device installation in six long-term care } \\
\text { facilities and one chronic care hospital in the US, plus a } \\
\text { control group. Injury data was collected for an average of } \\
38.9 \text { months pre-intervention and } 51.2 \text { months post- } \\
\text { intervention. }\end{array}$ & $\begin{array}{l}\text { The total lift and sit-stand lift were rated by patients as more } \\
\text { comfortable }(p \leq 0.007) \text { and safe }(p \leq 0.010) \text {; the majority of patients } \\
\text { found the devices to be comfortable and safe. }\end{array}$ \\
\hline $\begin{array}{l}\text { Campo et al. } \\
2013 \text { [55] }\end{array}$ & $\begin{array}{l}\text { A retrospective cohort study comparing intervention }(\mathrm{n}=784) \\
\text { and non-intervention }(\mathrm{n}=507) \text { patient groups - occurring } \\
\text { historically within the same rehabilitation unit of a US } \\
\text { hospital at different time periods. Intervention consisted of a } \\
\text { SPH programme. }\end{array}$ & $\begin{array}{l}\text { Both groups had comparable admission mobility scores; no } \\
\text { significant differences were found in discharge mobility scores } \\
\text { between the two groups, except in the group that had high mobility } \\
\text { on admission. These patients performed better with the SPH } \\
\text { programme. }\end{array}$ \\
\hline $\begin{array}{l}\text { Gucer et al. } \\
2013 \text { [56] }\end{array}$ & $\begin{array}{l}\text { Directors of nursing care }(\mathrm{N}=271) \text { provided faculty } \\
\text { information on powered mechanical lift availability and } \\
\text { lifting policy. Data was linked by the authors to mobility- } \\
\text { related resident outcomes from the Centers for Medicare \& } \\
\text { Medicaid Services Minimum Data Set Quality Indicators. }\end{array}$ & $\begin{array}{l}\text { Four of six Quality Indicators improved with number of lifts, but } \\
\text { were highest for sit-stand lift use. Facilities with the maximum } \\
\text { number of lifts had a lower incidence of pressure ulcers compared } \\
\text { with facilities with the fewest lifts ( } 10 \% \text { vs. } 16 \% \text {, respectively), and a } \\
\text { lower number of bedfast residents ( } 2 \% v s .4 \% \text {, respectively). Falls, } \\
\text { however, were more frequent with increased lift use. }\end{array}$ \\
\hline
\end{tabular}

\section{In Relation to Cost Savings}

Although cost savings have been briefly discussed in this paper, in the context of evidence for the importance of SPH in healthcare, it is worth pointing out that cost comparisons in different studies and papers are very difficult to interpret let alone compare, as completely different systems of cost comparisons and savings are frequently used. The studies included here all report a cost decrease associated with ergonomics interventions. Of these, four are associated with lifting device introduction [41, 44, 45, 57], while the other four report cost improvements associated with introduction of an ergonomics programme [12, 15, 18, 51]. Further, Burdorf et al. point out that low back pain and other MSDs lead to indirect costs which may provide a strong incentive for ergonomic device introduction [43].

Table 3. Evidence summary - cost and SPH.

\begin{tabular}{|c|c|c|}
\hline $\begin{array}{l}\text { First author } \\
\text { and year }\end{array}$ & Summary of study & Evidence \\
\hline $\begin{array}{l}\text { Brophy et al. } \\
2001[15]\end{array}$ & $\begin{array}{l}\text { Assessment of a 5-step ergonomics programme in a } \\
525 \text {-bed nursing home. }\end{array}$ & $\begin{array}{l}\text { Yearly cost associated with back MSDs decreased from } \$ 201,100 \text { pre- } \\
\text { intervention to } \$ 91,800 \text { post- intervention. During the } 5 \text { years following } \\
\text { implementation, it was calculated that } \$ 546,500 \text { was saved, more than } \\
\text { three times the expenditure for lifting and other equipment (a total of } \\
\$ 163,910) \text {. }\end{array}$ \\
\hline $\begin{array}{l}\text { Li et al. } 2004 \\
{[41]}\end{array}$ & $\begin{array}{l}\text { Effectiveness of mechanical patient lifts in a } \\
\text { population of } 36 \text { workers at a community hospital via } \\
\text { pre- and post-intervention survey. }\end{array}$ & $\begin{array}{l}\text { Adjusted lost day injury rates and annual workers' compensation costs } \\
\text { were decreased (from } \$ 484 \text { to } \$ 151 \text { per full-time equivalent post- } \\
\text { intervention). }\end{array}$ \\
\hline $\begin{array}{l}\text { Chhokar et al. } \\
2005[45]\end{array}$ & $\begin{array}{l}\text { Assessment of overhead lifts in an extended care } \\
\text { facility, with analysis of injury trends over } 3 \text { years pre- } \\
\text { intervention, and } 3 \text { years post-intervention. }\end{array}$ & $\begin{array}{l}\text { An estimated total saving of } \$ 1,257,605 \text { was made over a } 3 \text {-year post- } \\
\text { intervention period (based on the presumption that claims costs would } \\
\text { have continued to rise throughout this period). Even assuming that costs } \\
\text { plateaued, the authors still calculate a saving of } \$ 412,754 \text {. }\end{array}$ \\
\hline $\begin{array}{l}\text { Nelson et al. } \\
2006[12]\end{array}$ & $\begin{array}{l}\text { Implementation of an ergonomics programme in } 23 \\
\text { high-risk units ( } \mathrm{N}=875 \text { nursing staff). Costs/savings } \\
\text { were compared over a nine-month pre-intervention, } \\
\text { and a nine-month post-intervention period. }\end{array}$ & $\begin{array}{l}\text { The initial cost investment for the equipment was calculated as being } \\
\text { recovered in approximately } 3.75 \text { years. The cost of worker medical } \\
\text { treatment decreased from } \$ 95,091 \text { to } \$ 49,244 \text {, the cost of compensation } \\
\text { decreased from } \$ 134,763 \text { to an estimated } \$ 35,200 \text {, and the cost of lost } \\
\text { personal day productivity decreased from } \$ 55,743 \text { to } \$ 49,352 \text {. Total } \\
\text { savings on overall injury costs were calculated to be } \$ 245,727 \text {. }\end{array}$ \\
\hline $\begin{array}{l}\text { Miller et al. } \\
2005[44]\end{array}$ & $\begin{array}{l}\text { A pre- and post-intervention comparative study } \\
\text { assessing the effectiveness of ceiling lift introduction } \\
\text { on patient handling injuries. }\end{array}$ & $\begin{array}{l}\text { From the first two pre-intervention years to the end of the one-year } \\
\text { intervention period, a } 70 \% \text { decrease in claims cost (a decrease of } 18 \text { days } \\
\text { lost) was reported, compared with an increase of } 241 \% \text { in claims cost at } \\
\text { the comparison facility (an increase of } 499 \text { days lost). }\end{array}$ \\
\hline
\end{tabular}




\begin{tabular}{|c|c|c|}
\hline $\begin{array}{c}\text { First author } \\
\text { and year }\end{array}$ & Summary of study & Evidence \\
\hline $\begin{array}{l}\text { Charney et al. } \\
2006 \text { [51] }\end{array}$ & $\begin{array}{l}\text { Data was compared on patient handling injuries before } \\
\text { and after implementation of a 'zero-lift' programme in } \\
31 \text { US hospitals (replacement of manual patient lifting, } \\
\text { transferring and repositioning with mechanical } \\
\text { lifting/other devices). }\end{array}$ & $\begin{array}{l}\text { Average total incurred losses per claim decreased from } \$ 6,510 \text { to } \$ 4,991 \text {, } \\
\text { following the implementation of a 'zero-lift' programme in } 31 \text { hospitals in } \\
\text { the US. }\end{array}$ \\
\hline $\begin{array}{l}\text { Garg \& } \\
\text { Kapellusch } 2012 \\
{[18]}\end{array}$ & $\begin{array}{l}\text { Long-term effects of ergonomic programme } \\
\text { implementation with patient handling device } \\
\text { installation in six long-term care facilities and one } \\
\text { chronic care hospital, plus a control group. Injury data } \\
\text { was collected for an average of } 38.9 \text { months pre- } \\
\text { intervention and } 51.2 \text { months post-intervention. }\end{array}$ & $\begin{array}{l}\text { A mean saving of } \$ 71,822 \text { per year in worker compensation costs related } \\
\text { to patient-handling activities was reported, with a decrease in workers' } \\
\text { compensation costs of } 90.6 \%(\mathrm{p}<0.001) \text {. }\end{array}$ \\
\hline $\begin{array}{l}\text { Lipscomb et al. } \\
2012 \text { [57] }\end{array}$ & $\begin{array}{l}\text { An analysis of direct costs associated with } \\
\text { compensation claims for MSD injury over a 13-year } \\
\text { period. }\end{array}$ & $\begin{array}{l}\text { Policy change and cost of lifting equipment resulted in an immediate } \\
\text { decline in mean costs per injury claim, and costs per full-time equivalent, } \\
\text { with the proportion of claims resulting in paid lost time decreased from } \\
12.5 \% \text { pre-intervention, to } 7.4 \% \text { post-intervention. }\end{array}$ \\
\hline
\end{tabular}

\section{What is Missing?}

Although there is a large body of research on ergonomic device introduction and SPH programmes, most of this focuses on the healthcare provider. A number of these studies are also underpowered - being either small [13, 14, 41, $44,56]$, not randomised [4, 16, 46, 42, 49, 52], or lacking appropriate controls $[4,12,16,17,45,49,50]$. Several studies are also based on self-reported data $[6,14,42,44]$. When Amick et al. investigated the effects on musculoskeletal health status of occupational safety and health interventions in healthcare settings in a systematic review, they found only 40 relevant primary prevention intervention studies. Of these, only two were defined as high-quality [58]. Burdorf et al. point out that intervention studies with a sufficiently long follow-up period are frequently not available [43], therefore there is a need for more long-term follow-up studies. Further, a number of analysed intervention studies are underpowered to substantially demonstrate ergonomic device effectiveness. Variable efficacy is also seen in many studies - either because the study is underpowered, does not include a long-enough follow-up period to demonstrate efficacy, or because it is difficult to demonstrate causality in the association between manual patient lifting and MSDs [43]. While it is possible to draw conclusions based on the available studies, there is a need for adequately powered high-quality RCTs of multifactor interventions. These should help us to answer questions about the effectiveness of intervention combinations in preventing MSDs in nurses, and also provide guidance on further prevention strategy [24]. It is, however, difficult to implement a true experimental design on studies of ergonomic devices in the workplace because healthcare workplaces tend to be subject to changes which may interfere with the effects of the intervention. Further, large intervention studies with a follow-up period of 3-4 years are required, which may not be feasible in the workplace [43].

In particular, there are gaps in the literature relating to recipients of healthcare - it would be valuable to see more data on how implementation of SPH programmes affects the patient. Only one direct comparison relating specifically to SPH in patients was found [54], of the other studies included, one was not a direct comparison [55], and the other was a retrospective analysis relying on secondary data, with no control group [4]. High-quality RCTs are needed to investigate this relationship in more detail, providing further evidence to support the effect of SPH programmes on mobility. There is a link between improved patient mobility and pressure ulcer prevention [28], and there is also some evidence that SPH programmes improve patient mobility [54, 55]; increased lifting device use may also reduce pressure ulcer incidence [56]. It would, however, be valuable to investigate a direct link between SPH programme implementation and quality of care-related issues, such as pressure ulcers, incontinence and falls. There is also limited evidence on the effect of SPH programmes on bariatric patient care specifically. As SPH protocols with pre-admission development of a bariatric patient handling plan are considered to be essential for effective care of bariatric patients [59], it would be valuable to follow up this research with a comparative study, including patient feedback on device use. There is also limited evidence on the relationship between SPH programme implementation and patient quality of life and physical functioning, again, further studies would provide valuable data. Patient satisfaction is also an important healthcare outcome, as satisfied patients are more likely to comply with treatment and may therefore have better outcomes. They are also more likely to take an active role in their own care - an important outcome in patients with bariatric or other long-term conditions [60]. Patient satisfaction is also increasingly impacting on healthcare funding [61], and increased consumerism in healthcare means that patient satisfaction ratings will have a large impact on which hospitals are chosen 
by patients for their treatment [62]. As SPH programmes appear to have a positive effect on patient quality of life [4, $63]$, it would be valuable to see how implementation of such a programme correlates with patient satisfaction.

\section{DISCUSSION}

MSDs are a major source of injury to healthcare workers [21], with manual patient handling considered to be the largest risk factor for overexertion injuries in healthcare workers $[19,24]$. Under-reporting of injuries is reportedly common $[1,12]$, so the scale of the problem may be even greater [12].

A range of technologies and techniques are available to facilitate SPH - ergonomic equipment may include patient lifts (floor and ceiling), while training in back care, body mechanics and lifting techniques, as well as in proper use of equipment for SPH, is also valuable. Single interventions, however, appear to facilitate less improvement than multiple interventions within a SPH programme. A systematic review by Freiberg et al. [64], found no convincing evidence for any benefit to small patient handling aid use in preventing MSDs, although they also admit that they could find no convincing evidence for the opposing point of view, and mention that the studies used were low quality, with insufficient methodology and high risk of bias. It appears that health promotion in the workplace is most effective as a combination of individual and environmental influences; targeting individual behaviour only is likely to yield minimal benefit, compared with interventions that also target the organisation and work design [65]. The effectiveness of training is limited without the availability of engineering controls such as ergonomic devices [14], and the most effective interventions appear to be those that combine both, in the form of a structured SPH programme with executive leadership [5, 6].

Implementation of a structured SPH programme has been shown to reduce the incidence rate for MSDs and the number of lost workdays [12, 13, $15-18]$. In patients, mobility outcomes were improved with a SPH and mobility programme [54, 55], and patients reported greater comfort and security with ergonomic device use [6]. Implementation of a SPH programme can also improve the quality of patient care, and quality of life [4], while cost savings have also been demonstrated with SPH programme implementation $[15,44,45,51]$.

There can, however, be barriers to effective implementation of a SPH programme. Resistance to change is one; ergonomic device use can be variable, with nurses sometimes choosing not to use a device when it is recommended, or to the extent that it was intended. Reasons given include: poor access, insufficient training, lack of space for use or storage, inadequate staffing, or increased time required compared with manual methods [5, 7, 41, 46]. Knibbe et al. found the behaviour change required in nurses was a major issue with implementation of device use-to adjust from two or more persons to only one required an adjustment in attitude for the nurse to realise that this was still safe practice [47]. The importance of follow up in this situation was emphasized by the authors [47]. Koppelaar et al. recommend use of workplace policies that target organisational factors relating to ergonomic device implementation, as well as policies targeting individuals, such as training [46]. As Burdorf et al. point out, SPH interventions need to be implemented to a high degree in the target population - requiring a change in the culture of the implementing facility [43]. Cultural change is the main aim of a SPH programme, with behavioural change at all levels required to successfully introduce the processes laid out in the programme. Introduction of new behaviours can be slow, and change initiatives difficult to maintain [32], hence the importance of a formalised programme incorporating change advocates, structured training, and support at all levels from management to front-line employees.

The safety climate in a hospital is defined by the personnel - their values, beliefs and behaviours. Peers and managers also have a role to play in influencing safety attitudes and behaviours, and in establishing work processes and climate. Both individual consideration and strong leadership are required to implement cultural change through use of a SPH programme [32]. Culture is defined as a shared set of beliefs, values and behaviours; it can be manipulated and altered by leaders and members of an organisation [63]. If there is no culture of safety present in the organisation and promoted by senior leaders, it will be difficult for the organisation to achieve success with any safety endeavour [66]. Culture can be a broad, overarching presence in an organisation, but should also be easily condensed to a specific programme. A fundamental change in culture is also necessary to ensure that innovations introduced to improve patient safety actually achieve their potential [67].

Implementing cultural standards requires a multi-disciplinary approach involving a cross-section of employees (nurses, aids, transport, etc.), and leadership that establishes these standards as a cultural norm in a fair and just manner. Leadership is necessary to ensure both initial and on-going compliance; making conscious choices about patient safety is the responsibility of management [68]. Although top-down executive leadership is important, however, a 'bottom-up' 
strategy involving the staff is also vital. A successful approach would combine a top-down approach managing work system structure and processes, while a bottom-up approach supports successful implementation [50].

Training, supported by a suitable management process, is vital, as is employee motivation, and incentives to changing work culture. Menzel et al. point out that evidence-based education and tutoring in patient-care ergonomics is important for nurses in training, and that implementing SPH training programmes into the nursing curriculum is a good investment in the future nursing workforce [11].

The overall aim of a SPH programme is the complete integration of SPH practices into healthcare education and practice. This requires a change in belief as to the value of SPH and the importance of protecting both caregivers and patients. Introduction of new behaviours can be slow, and change initiatives difficult to maintain, while change and resistance are closely linked. Employee resistance to programme implementation may include distraction (due to simultaneous implementation of too many initiatives), believing the change is unnecessary, lack of enthusiasm and lack of communication. Manager scepticism at higher levels may also transmute down to staff - therefore the wellestablished need for strong leadership by management, and advocates from within staff. A direct link has been demonstrated between the safety climate of a hospital and indicators of potential safety events, with perception of safety climate by front-line personnel reflecting actual hospital safety climate [69]. Use of workplace policies that target organisational factors as well as individuals are therefore recommended. They provide the most value in implementing a change in attitude as well as practice $[7,41,46,70]$. Implementing cultural change through use of a SPH programme requires both individual thought and strong leadership. This derives from the implementation from the beginning of a thoughtful plan, based on input from those affected, with realistic timelines. Commitment by both management and staff to supporting the change is also vital [21,32], and huddles are a valuable tool to create both staff commitment and project ownership.

Table 4. Relating the evidence to the stages of an SPH programme-from the patient perspective

\begin{tabular}{|c|c|c|}
\hline Programme stage & Supporting evidence & Study author(s) \\
\hline Stage 1: improved patient mobility & Improved mobility outcomes & $\begin{array}{l}\text { Arnold et al. } 2012 \text { [54]; Campo et al. } \\
2013 \text { [55] }\end{array}$ \\
\hline Stage 2: improved vital bodily functions & $\begin{array}{l}\text { Improved physical functioning, improved urinary } \\
\text { continence, improved daytime alertness }\end{array}$ & Nelson et al. 2008 [4] \\
\hline $\begin{array}{l}\text { Stage 3: reduced risk of healthcare } \\
\text { associated/immobility-acquired complications }\end{array}$ & $\begin{array}{l}\text { Improved urinary continence; improved } \\
\text { mobilisation }\end{array}$ & $\begin{array}{l}\text { Nelson et al. } 2008 \text { [4]; Arnold et al. } 2012 \\
\text { [54]; Campo et al. } 2013 \text { [55] }\end{array}$ \\
\hline $\begin{array}{l}\text { Stage 4: improved rate of recovery, greater quality of } \\
\text { life and reduced length of stay }\end{array}$ & $\begin{array}{l}\text { Improved quality of patient care, and quality of } \\
\text { life }\end{array}$ & Nelson et al. 2008 [4] \\
\hline Stage 5: reduced need for assistance & $\begin{array}{l}\text { Improved physical functioning, improved urinary } \\
\text { continence, improved engagement in activities, } \\
\text { lower fall risk, and improved daytime alertness }\end{array}$ & Nelson et al. 2008 [4] \\
\hline $\begin{array}{l}\text { Stage 6: reduced strain related injury and better staff } \\
\text { productivity }\end{array}$ & $\begin{array}{l}\text { Reduction in incidence rate for back MSDs, } \\
\text { number of lost workdays, reduction in perceived } \\
\text { shoulder and lower back strain }\end{array}$ & $\begin{array}{l}\text { Garg et al. } 1992 \text { [13]; Brophy et al. } 2001 \\
\text { [15]; Owen et al. } 2002 \text { [6]; Collins et al. } \\
\text { 2004 [16]; Fujishiro et al. } 2005 \text { [17]; } \\
\text { Nelson et al. } 2006 \text { [12]; Garg } 2012 \text { [18] }\end{array}$ \\
\hline $\begin{array}{l}\text { Stage 7: improved retention through less sick leave } \\
\text { and turnover }\end{array}$ & $\begin{array}{l}\text { Greater reduction in lost workdays, reduced } \\
\text { number of injury claims }\end{array}$ & $\begin{array}{l}\text { Brophy et al. } 2001 \text { [15]; Collins et al. } \\
2004 \text { [16]; Fujishiro et al. } 2005 \text { [17]; } \\
\text { Nelson et al. } 2006 \text { [12]; Garg et al. } 2012 \\
\text { [18]; Charney et al. 2006 [51] }\end{array}$ \\
\hline $\begin{array}{l}\text { Stage 8: improved quality of care and financial } \\
\text { outcomes }\end{array}$ & $\begin{array}{l}\text { Savings in compensation costs for back MSDs, } \\
\text { and in days lost due to injury, reduced number of } \\
\text { injury claims, improved quality of patient care, } \\
\text { improved patient urinary continence }\end{array}$ & $\begin{array}{l}\text { Nelson et al. } 2008 \text { [4]; Brophy et al. } \\
2001 \text { [15]; Garg et al. } 2012 \text { [18]; } \\
\text { Chhokar et al. } 2005 \text { [44]; Miller et al. } \\
2006 \text { [45]; Charney et al. } 2006 \text { [51] }\end{array}$ \\
\hline
\end{tabular}

\section{CONCLUSION}

There are a large number of publications investigating the value of SPH programmes in improving conditions in the healthcare environment for both patients and healthcare workers. It appears that multiple interventions within a SPH programme are more effective at facilitating improvement than single interventions. There is evidence that implementation of a structured SPH programme can reduce MSDs in healthcare workers, while improving patient mobility outcomes and quality of life. Our investigation, however, has demonstrated that a number of these studies are underpowered, and many are based on self-reported data. Further, there are gaps in the literature relating to SPH and its 
impact on the patient. Most of the published studies reviewed were performed in North America, or in Northern Europe. It would be valuable for comparison to see well-powered studies from a greater variety of countries, or with a global application. This review was also limited by only using English-language studies.

The need for high-quality RCTs addressing the relationship between SPH programmes and health improvements for both patients and healthcare workers is highlighted by this review. As previously mentioned, the purpose of this review was to provide an evidential overview of the available evidence for the effectiveness of SPH programme implementation. As the publications used are derived from a number of different countries (mainly those in Europe and North America), different terminology is used. This is one of the main problems in preparing reviews of this nature and as such can make it difficult to directly compare publications. Our aim has therefore been to provide a brief overview of the papers that we have identified as supporting evidence, followed by their consideration on the basis of what is still needed as evidence.

The value of a SPH programme cannot be understated. While interventions such as appropriate aids, equipment and training have an impact on improving conditions for both healthcare workers and patients, there is value to the implementation of a structured programme. Such a programme should identify risks, incorporate cultural change, and include employees at all levels, giving them a defined role and ownership in programme implementation. The importance of cultural change in the successful implementation of a SPH programme is therefore highlighted. As discussed above, there are barriers to successful SPH programme intervention, and work culture is a major one. As the safety climate in a healthcare facility is defined by its personnel, the first step is to introduce a change in culture, to facilitate a change in practice. This is important at all levels, with safety attitudes and behaviours being directly influenced by healthcare worker peers and managers.

Although there are definite cost advantages to implementing SPH programmes, the advantages in improved working conditions for caregivers, and improved care conditions for patients, are even greater. This is particularly pertinent given the increasing age of the nursing workforce, and the increasing demands of a population that is living longer while at the same time requiring expert long term care.

\section{LIST OF ABBREVIATIONS}

$\begin{array}{lll}\text { ANA } & = & \text { American nurses association } \\ \text { FIM } & = & \text { Functional independence measure } \\ \text { MS } & = & \text { Musculoskeletal } \\ \text { MSDs } & = & \text { Musculoskeletal disorders } \\ \text { OSHA } & = & \text { Occupational safety and health administration } \\ \text { RCT } & = & \text { Randomised controlled trial } \\ \text { SPH } & = & \text { Safe patient handling } \\ \text { TR } & = & \text { Technical report }\end{array}$

\section{CONFLICT OF INTEREST}

Mr Rob Humrickhouse and Ms Hanneke JJ Knibbe have from time to time provided expert consultancy services to ArjoHuntleigh.

\section{ACKNOWLEDGEMENTS}

The authors would like to acknowledge Ms Rebecca Drake for editorial and research assistance in the preparation of this article.

\section{REFERENCES}

[1] Matz MW, Leib R. Chapter 1: Rationale for including the PHAMA in the 2010 Guidelines for Design and Construction of Health Care Facilities. In: Cohen M, Nelson G, Green D, Eds. PHAMA Patient Handling and Movement Assessments: A White Paper. The Facility Guidelines Institute 2010.

[2] Smedley J, Egger P, Cooper C, Coggon D. Manual handling activities and risk of low back pain in nurses. Occup Environ Med 1995; 52(3): $160-3$.

[http://dx.doi.org/10.1136/oem.52.3.160] [PMID: 7735387]

[3] Burdorf A, Jansen JP. Predicting the long term course of low back pain and its consequences for sickness absence and associated work disability. Occup Environ Med 2006; 63(8): 522-9. 
[http://dx.doi.org/10.1136/oem.2005.019745] [PMID: 16849528]

[4] Nelson A, Collins J, Siddharthan K, Matz M, Waters T. Link between safe patient handling and patient outcomes in long-term care. Rehabil Nurs 2008; 33(1): 33-43.

[http://dx.doi.org/10.1002/j.2048-7940.2008.tb00190.x] [PMID: 18236890]

[5] Yassi A, Cooper JE, Tate RB, et al. A randomized controlled trial to prevent patient lift and transfer injuries of health care workers. Spine 2001; 26(16): 1739-46.

[http://dx.doi.org/10.1097/00007632-200108150-00002] [PMID: 11493843]

[6] Owen BD, Keene K, Olson S. An ergonomic approach to reducing back/shoulder stress in hospital nursing personnel: a five year follow up. Int J Nurs Stud 2002; 39(3): 295-302. [http://dx.doi.org/10.1016/S0020-7489(01)00023-2] [PMID: 11864653]

[7] Evanoff B, Wolf L, Aton E, Canos J, Collins J. Reduction in injury rates in nursing personnel through introduction of mechanical lifts in the workplace. Am J Ind Med 2003; 44(5): 451-7.

[http://dx.doi.org/10.1002/ajim.10294] [PMID: 14571508]

[8] Hignett S. Intervention strategies to reduce musculoskeletal injuries associated with handling patients: a systematic review. Occup Environ Med 2003; 60(9): E6. [http://dx.doi.org/10.1136/oem.60.9.e6] [PMID: 12937202]

[9] ISO. Ergonomics: Manual Handling of People in the Healthcare Sector. Technical Report 12296. Switzerland: International Organisation for Standardization 2012.

[10] Taylor JA, Dominici F, Agnew J, Gerwin D, Morlock L, Miller MR. Do nurse and patient injuries share common antecedents? An analysis of associations with safety climate and working conditions. BMJ Qual Saf 2012; 21(2): 101-11. [http://dx.doi.org/10.1136/bmjqs-2011-000082] [PMID: 22016377]

[11] Menzel NN, Hughes NL, Waters T, Shores LS, Nelson A. Preventing musculoskeletal disorders in nurses: a safe patient handling curriculum module for nursing schools. Nurse Educ 2007; 32(3): 130-5.

[http://dx.doi.org/10.1097/01.NNE.0000270227.61414.79] [PMID: 17496508]

[12] Nelson A, Matz M, Chen F, Siddharthan K, Lloyd J, Fragala G. Development and evaluation of a multifaceted ergonomics program to prevent injuries associated with patient handling tasks. Int J Nurs Stud 2006; 43(6): 717-33. [http://dx.doi.org/10.1016/j.ijnurstu.2005.09.004] [PMID: 16253260]

[13] Garg A, Owen B. Reducing back stress to nursing personnel: an ergonomic intervention in a nursing home. Ergonomics 1992; 35(11): $1353-75$. [http://dx.doi.org/10.1080/00140139208967398] [PMID: 1425566]

[14] Lynch RM, Freund A. Short-term efficacy of back injury intervention project for patient care providers at one hospital. AIHAJ 2000; 61(2): 290-4.

[http://dx.doi.org/10.1080/15298660008984539] [PMID: 10782202]

[15] Brophy MO, Achimore L, Moore-Dawson J. Reducing incidence of low-back injuries reduces cost. AIHAJ 2001; 62(4): 508-11. [http://dx.doi.org/10.1080/15298660108984653] [PMID: 11549145]

[16] Collins JW, Wolf L, Bell J, Evanoff B. An evaluation of a "best practices" musculoskeletal injury prevention program in nursing homes. Inj Prev 2004; 10(4): 206-11.

[http://dx.doi.org/10.1136/ip.2004.005595] [PMID: 15314046]

[17] Fujishiro K, Weaver JL, Heaney CA, Hamrick CA, Marras WS. The effect of ergonomic interventions in healthcare facilities on musculoskeletal disorders. Am J Ind Med 2005; 48(5): 338-47. [http://dx.doi.org/10.1002/ajim.20225] [PMID: 16254947]

[18] Garg A, Kapellusch JM. Long-term efficacy of an ergonomics program that includes patient-handling devices on reducing musculoskeletal injuries to nursing personnel. Hum Factors 2012; 54(4): 608-25. [http://dx.doi.org/10.1177/0018720812438614] [PMID: 22908684]

[19] Workplace safety and health topics: safe patient handling 2014. [Website viewed 17.03.14], Available from: http://www.cdc.gov/ niosh/topics/safepatient/.

[20] Martimo K-P, Verbeek J, Karppinen J, et al. Effect of training and lifting equipment for preventing back pain in lifting and handling: systematic review. BMJ 2008; 336(7641): 429-31.

[http://dx.doi.org/10.1136/bmj.39463.418380.BE] [PMID: 18244957]

[21] Alliance AO. Beyond getting started: a resource guide for implementing a safe patient handling program in the acute care setting Second Edition; revised Summer 2011. [Retrieved 2014 May 20] Available from: http://aohp.org/aohp/Portals/0/Documents/ AboutAOHP/BGS_Summer2011.pdf.

[22] Safe Patient Handling \& Mobility. Interprofessional National Standards across the Care Continuum. Silver Spring, Maryland: American Nurses Association 2013.

[23] Occupational Safety and Health Administration, United States Department of Labor. Safety and Health Topics: Safe Patient Handling [2014 March 13]; Available from: https://www.osha.gov/SLTC/healthcarefacilities/safepatienthandling.html. 
[24] Yassi A, Lockhart K. Work-relatedness of low back pain in nursing personnel: a systematic review. Int J Occup Environ Health 2013; 19(3): 223-44.

[http://dx.doi.org/10.1179/2049396713Y.0000000027] [PMID: 23885775]

[25] Alperovitch-Najenson D, Treger I, Kalichman L. Physical therapists versus nurses in a rehabilitation hospital: comparing prevalence of workrelated musculoskeletal complaints and working conditions. Arch Environ Occup Health 2014; 69(1): 33-9. [http://dx.doi.org/10.1080/19338244.2012.719555] [PMID: 23930794]

[26] Campo M, Weiser S, Koenig KL, Nordin M. Work-related musculoskeletal disorders in physical therapists: a prospective cohort study with 1year follow-up. Phys Ther 2008; 88(5): 608-19. [http://dx.doi.org/10.2522/ptj.20070127] [PMID: 18276935]

[27] Pellatt GC. The safety and dignity of patients and nurses during patient handling. Br J Nurs 2005; 14(21): 1150-6. [http://dx.doi.org/10.12968/bjon.2005.14.21.20076] [PMID: 16475436]

[28] Cox J. Predictors of pressure ulcers in adult critical care patients. Am J Crit Care 2011; 20(5): 364-75. [http://dx.doi.org/10.4037/ajcc2011934] [PMID: 21885457]

[29] Prevention and Treatment of Pressure Ulcers: Clinical Practice Guideline. Washington, DC: National Pressure Ulcer Advisory Panel 2009.

[30] Guideline for the Prevention and Management of Pressure Ulcers. Mt Laurel, NJ: Wound, Ostomy and Continence Nurses Society 2010.

[31] Gallagher S, Harrington S, Kumpar D, et al. White paper: Advancing the Science and Technology of Progressive Mobility. Association of Safe Patient Handling Professionals (ASPHP); American Nurses Association 2011. [Retrieved 2014 May 20] Available from: http://www.asphp.org/wp-content/uploads/2011/05/1400387-ASPHP_ANA_Whitepaper-HR.pdf.

[32] Haney LL, Wright L. Sustaining staff nurse support for a patient care ergonomics program in critical care. Crit Care Nurs Clin North Am 2007; 19(2): 197-204.

[http://dx.doi.org/10.1016/j.ccell.2007.02.003] [PMID: 17512475]

[33] The Library of Congress Bill Text $113^{\text {th }}$ Congress (2013-2014): HR2480IH: Nurse and Health Care Worker Protection Act of 2013. (Introduced in House - IH) 2013 [2014 March 17]; Available from: http://thomas.loc.gov/cgi-bin/query/z?c113:.H.R.2480.IH:/.

[34] de Castro AB. Handle With Care ${ }^{\circledR}$ : The American Nurses Association's campaign to address work-related musculoskeletal disorders. Online J Issues Nurs 2004; 9(3) Manuscript 2. [Retrieved 2014 May 22] Available from: http://www.nursingworld.org/ MainMenuCategories/ANAMarketplace/ANAPeriodicals/OJIN/TableofContents/Volume92004/No3Sept04/HandleWithCare.aspx.

[35] ANA Nursing World: Safe Patient Handling and Mobility (SPHM). [2014 August 25]; Available from: http://www.nursingworld.org/ MainMenuCategories/Policy-Advocacy/State/Legislative-Agenda-Reports/State-SafePatientHandling.

[36] ANA Nursing World: Safe Patient Handling and Mobility - Latest News. [Retrieved 2014 August 25]; Available from: http://www.rnaction.org/site/PageNavigator/nstat_take_action_sph_113.html.

[37] ANA Nursing World: Safe Patient Handling and Mobility: The Nurse and Health Care Worker Protection Act of 2013. (HR 2480) [2014 August 245]; Available from: http://www.rnaction.org/site/DocServer/SPHM_w_Finance.pdf?docID=2001.

[38] European Agency for Safety and Health at Work. Directive 90/269/EEC - manual handling of loads [2014 August 25]; Available from: https://osha.europa.eu/en/legislation/directives/provisions-on-workload-ergonomical-and-psychosocial-risks/osh-directives/6.

[39] UK Health and Safety Executive. Manual Handling Operations Regulations 1992. [Retrieved 2014 June 24]; Available from: http://www.hse.gov.uk/pubns/priced/123.pdf.

[40] Hignett S, Fray M, Battevi N, et al. International consensus on manual handling of people in the healthcare sector: Technical report ISO/TR 12296. Int J Indust Ergonomics 2014; 44: 191-5.

[41] Li J, Wolf L, Evanoff B. Use of mechanical patient lifts decreased musculoskeletal symptoms and injuries among health care workers. Inj Prev 2004; 10(4): 212-6. [http://dx.doi.org/10.1136/ip.2003.004978] [PMID: 15314047]

[42] Trinkoff AM, Brady B, Nielsen K. Workplace prevention and musculoskeletal injuries in nurses. J Nurs Adm 2003; 33(3): 153-8. [http://dx.doi.org/10.1097/00005110-200303000-00006] [PMID: 12629302]

[43] Burdorf A, Koppelaar E, Evanoff B. Assessment of the impact of lifting device use on low back pain and musculoskeletal injury claims among nurses. Occup Environ Med 2013; 70(7): 491-7.

[http://dx.doi.org/10.1136/oemed-2012-101210]

[44] Miller A, Engst C, Tate RB, Yassi A. Evaluation of the effectiveness of portable ceiling lifts in a new long-term care facility. Appl Ergon 2006; 37(3): 377-85.

[http://dx.doi.org/10.1016/j.apergo.2005.05.012] [PMID: 16380072]

[45] Chhokar R, Engst C, Miller A, Robinson D, Tate RB, Yassi A. The three-year economic benefits of a ceiling lift intervention aimed to reduce healthcare worker injuries. Appl Ergon 2005; 36(2): 223-9. [http://dx.doi.org/10.1016/j.apergo.2004.10.008] [PMID: 15694077]

[46] Koppelaar E, Knibbe HJ, Miedema HS, Burdorf A. The influence of ergonomic devices on mechanical load during patient handling activities in nursing homes. Ann Occup Hyg 2012; 56(6): 708-18.

[http://dx.doi.org/10.1093/annhyg/mes009] [PMID: 22393034] 
[47] Knibbe JJ, Knibbe NE, Waaijer E. Flying through the hospital: efficiency and safety of an ergonomic solution. Work 2012; 41(Suppl. 1): 5642-3. [PMID: 22317637]

[48] Holtermann A, Clausen T, Jørgensen MB, et al. Does rare use of assistive devices during patient handling increase the risk of low back pain? A prospective cohort study among female healthcare workers. Int Arch Occup Environ Health 2015; 88(3): 335-42. [http://dx.doi.org/10.1007/s00420-014-0963-4] [PMID: 25053444]

[49] Johnsson C, Carlsson R, Lagerström M. Evaluation of training in patient handling and moving skills among hospital and home care personnel. Ergonomics 2002; 45(12): 850-65.

[http://dx.doi.org/10.1080/00140130210160920] [PMID: 12487687]

[50] Hartvigsen J, Lauritzen S, Lings S, Lauritzen T. Intensive education combined with low tech ergonomic intervention does not prevent low back pain in nurses. Occup Environ Med 2005; 62(1): 13-7. [http://dx.doi.org/10.1136/oem.2003.010843] [PMID: 15613603]

[51] Charney W, Simmons B, Lary M, Metz S. Zero lift programs in small rural hospitals in Washington state: Reducing back injuries among health care workers. AAOHN J 2006; 54(8): 355-8. [http://dx.doi.org/10.1177/216507990605400803] [PMID: 16921866]

[52] Muto S, Muto T, Seo A, Yoshida T, Taoda K, Watanabe M. Effect of nursing assistance tools on preventing musculoskeletal pain among staff in schools for disabled children. J Occup Health 2008; 50(3): 245-50. [http://dx.doi.org/10.1539/joh.L7150] [PMID: 18408345]

[53] Kuijer PP, Verbeek JH, Visser B, et al. An evidence-based multidisciplinary practice guideline to reduce the workload due to lifting for preventing work-related low back pain. Ann Occup Environ Med 2014; $26: 16$. [http://dx.doi.org/10.1186/2052-4374-26-16] [PMID: 24999432]

[54] Arnold M, Radawiec S, Campo M, Wright LR. Changes in functional independence measure ratings associated with a safe patient handling and movement program. Rehabil Nurs 2011; 36(4): 138-44.

[http://dx.doi.org/10.1002/j.2048-7940.2011.tb00081.x] [PMID: 21721394]

[55] Campo M, Shiyko MP, Margulis H, Darragh AR. Effect of a safe patient handling program on rehabilitation outcomes. Arch Phys Med Rehabil 2013; 94(1): 17-22.

[http://dx.doi.org/10.1016/j.apmr.2012.08.213] [PMID: 22960275]

[56] Gucer PW, Gaitens J, Oliver M, McDiarmid MA. Sit-stand powered mechanical lifts in long-term care and resident quality indicators. J Occup Environ Med 2013; 55(1): 36-44. [http://dx.doi.org/10.1097/JOM.0b013e3182749c35] [PMID: 23138044]

[57] Lipscomb HJ, Schoenfisch AL, Myers DJ, Pompeii LA, Dement JM. Evaluation of direct workers' compensation costs for musculoskeletal injuries surrounding interventions to reduce patient lifting. Occup Environ Med 2012; 69(5): 367-72. [http://dx.doi.org/10.1136/oemed-2011-100107] [PMID: 22199366]

[58] Amick B, Tullar J, Brewer S, et al. Interventions in health-care settings to protect musculoskeletal health: A systematic review. Toronto: Institute for Work \& Health 2006.

[59] Muir M, Archer-Heese G. Essentials of a bariatric patient handling program. OJIN 2009; 14(1): Manuscript 5. [http://dx.doi.org/10.3912/OJIN.Vol14No1Man05]

[60] Hignett S. Embedding ergonomics in hospital culture: top-down and bottom-up strategies. Appl Ergon 2001; 32(1): 61-9. [http://dx.doi.org/10.1016/S0003-6870(00)00029-6] [PMID: 11209833]

[61] Diana A. Hospitals elevate patient satisfaction to the c-suite. InformationWeek Healthcare 2014. [Retrieved 2014 August 254]; Available from: http://www.informationweek.com/healthcare/leadership/hospitals-elevate-patient-satisfaction-to-the-c-suite/d/d-id/1127860.

[62] Dunn L. Patient experience: an increasingly critical hospital indicator. Becker's Hospital Review 2011. [Retrieved 2014 August 25]; Available from: http:/www.beckershospitalreview.com/hospital-management-administration/ patient-experience-an-increasingly-criticalhospital-indicator.html.

[63] Modaff DP, DeWine S, Butler J. Organizational communication: Foundations, challenges, and misunderstandings. $2^{\text {nd }}$ ed. Boston: Pearson Education 2011.

[64] Freiberg A, Euler U, Girbig M, et al. Does the use of small aids during patient handling activities lead to a decreased occurrence of musculoskeletal complaints and diseases? A systematic review. Int Arch Occup Environ Health 2015. [Epub ahead of print]. [PMID: 26467839]

[65] Shain M, Kramer DM. Health promotion in the workplace: framing the concept; reviewing the evidence. Occup Environ Med 2004; 61: $643-8,585$.

[66] Baldrige Criteria for Performance Excellence 1, Senior Leadership 2013-2014. [Retrieved 2014 August 25]; Available from: http://www.nist.gov/baldrige/publications/criteria.cfm.

[67] Nieva VF, Sorra J. Safety culture assessment: a tool for improving patient safety in healthcare organizations. Qual Saf Health Care 2003; 12(Suppl. 2): ii17-23.

[http://dx.doi.org/10.1136/qhc.12.suppl_2.ii17] [PMID: 14645891] 
[68] Dunbar S. Safety Huddles. Advance Healthcare Network for Nurses 2008; 10(19): 23. [Retrieved 2014 August 24]; Available from: http://nursing.advanceweb.com/Article/Safety-Huddles-1.aspx.

[69] Singer S, Lin S, Falwell A, Gaba D, Baker L. Relationship of safety climate and safety performance in hospitals. Health Serv Res 2009; 44(2 Pt 1): 399-421.

[http://dx.doi.org/10.1111/j.1475-6773.2008.00918.x] [PMID: 19178583]

[70] Nova Scotia Health Research Foundation. Musculoskeletal Injury Tracking and Prevention Jurisdictional Review: Literature Review. 2013.

(C) Humrickhouse and Knibbe; Licensee Bentham Open

This is an open access article licensed under the terms of the Creative Commons Attribution-Non-Commercial 4.0 International Public License (CC BY-NC 4.0) (https://creativecommons.org/licenses/by-nc/4.0/legalcode), which permits unrestricted, non-commercial use, distribution and reproduction in any medium, provided the work is properly cited. 